\title{
On cosmopolitan translation and how worldviews might change
}

\author{
Anthony Pym \\ School Languages and Linguistics, The University of Melbourne, Australia \\ E-mail: anthony.pym@urv.cat; anthony.pym@unimelb.edu.au
}

\author{
In celebration of the warm hospitality shown to me by Professor Ilse \\ Feinauer and her fellow South Africans.
}

\begin{abstract}
The theorisation of cosmopolitanism can be dated from Kant's "right to hospitality", where the reciprocal welcoming of foreigners is supposed to lead to universal understanding. Differences in languages and religions are recognised as obstacles in the way to that ideal, yet Kant has little to say about how to get around their differences - translation is strangely absent. A role for translation in cosmopolitanism nevertheless appears in the discourses that assume an age of effective economic globalisation. The cosmopolitanisms elaborated by Ulrich Beck (2004/2006) and Gerard Delanty (2009), among many others, adopt a sense of cultural translation that requires no anterior text, no language barrier, and thus no mediator: the cosmopolitan becomes an intercultural space where relations transform subjects. Those views may be tested on the narratives of three Afrikaans-speaking intellectuals who recount how they grew up under Apartheid and progressively dissented from totalitarian discourse. The concepts of cosmopolitan translation are found to explain some of the narratives involved, particularly when the self is seen through the eyes of the other, yet strong social and national frames are still in force, boycotts counter hospitality and reinforce national frames, and language translation is found to be relatively unimportant in a milieu of polyglots.
\end{abstract}

Keywords: cosmopolitanism; hospitality; translation; Apartheid

\section{Introduction}

In August 2019 some 18,000 fires were ablaze in the Amazon, burning 500,000 hectares in 16 days. The fires opened future grazing land for Brazilian pastoralists but presented severe challenges for our planet's climate. There were significant demonstrations in front of Brazilian embassies in the major capitals of the world, pressure on a G7 meeting in France, and a consequent about-face on the part of the Brazilian government, which sent its military to put out the fires, accepted financial aid for the cause, but was nevertheless happy enough that the farmers had opened new land. 
This, by all accounts, would be a great success for international climate activists, many of whom were effectively moved to action for a cause that is geographically far from their immediate concerns. Their action required commitment to a cause that was above the level of national politics, social class, or ethnic identity: this was a fight for the future of the world's climate. The fact that so many people could be mobilised could be seen as a victory for cosmopolitanism, for the general call to act as citizens of the world, on a level of shared self-interest that is, these days, concomitant with the interests of the planet. How that can happen, and how it can happen more consistently than in this one-off case, is perhaps the most engaging problem of cosmopolitan studies. As Chanda (2007: ix) puts it, the task is to "explain why an electrician in New Haven cares about the Brazilian rain forest". That an electrician cares is laudable; that not all electricians care might remain the problem to be worked on.

Here I adopt this kind of ecological cosmopolitanism as an ideal that we might work toward, and as an attitude that we might transfer to many other fields of activity. Cosmopolitanism in this sense is clearly no longer the classical "citizen of the world", nor the $19^{\text {th }}$-century upperclass multilingual fop who substituted voyages for social responsibility. It is, happily, a rather more serious and subtle theorising of the inadequacies of the national frame, in politics, culture, sociology, and many things in between. The name is still unfortunate, I suspect, since the latterday universalists and sundry fops linger on. Yet there it is, gaining adepts as it addresses some of the more important issues of our age. And as it talks, as it attempts to speak to politics and people going beyond the nation state, one of cosmopolitanism's key terms has become "translation". My humble purpose here is to look at what that term might mean in this context and to see how it can relate to a few people who act not just beyond their immediate self-interest, but also beyond investment in merely local interests.

\section{Kant, hospitality, and language}

One of the key texts for contemporary cosmopolitanism has become Kant's 1795 essay "On Perpetual Peace" (Zum ewigen Frieden), in large measure thanks to readings of it by Habermas (1995), Derrida (1997/2001), and Derrida and Dufourmantelle (2000). Kant's essay concludes with a vision of a future in which there is no war between nations because all subscribe to a "cosmopolitan constitution", glossed as "cosmopolitan right" (Kant 1795/1903: 138). This partly takes the classical discourse of natural law and projects it onto a theoretical future. Yet it more importantly identifies one right as the key to the attainment of all others - the right to hospitality:

$[\mathrm{H}]$ ospitality signifies the claim of a stranger entering foreign territory to be treated by its owner without hostility. The latter may send him away again, if this can be done without causing his death; but, so long as he conducts himself peaceably, he must not be treated as an enemy.

(Kant 1795/1903: 137)

More contemporary parlance would speak about a "right to mobility": people can move from nation to nation and not be treated with hostility, and this right can then provide a basis for such things as the extraterritoriality of embassies and consulates, the international system of passports, and indeed the rights of refugees and asylum seekers. For Kant, the right to hospitality is presumed to have a basis in a logic of distribution: 
This right to present themselves to society belongs to all humans in virtue of our common right of possession on the surface of the earth on which, as it is a globe, we cannot be infinitely scattered, and must in the end reconcile ourselves to existence side by side: at the same time, originally no one individual had more right than another to live in any one particular spot.

(Kant 1795/1903: 138; modified)

This is strange: an abstract geography of the individual, as if survival in most parts of the world did not depend on a community, on mutual support between individuals, on - in a word - some primary degree of social networking. I merely record the strange individualism and move on:

Uninhabitable portions of the surface, ocean and desert, split up the human community, but in such a way that ships and camels - "the ship of the desert" make it possible for men to come into touch with one another across these unappropriated regions and to take advantage of our common claim to the face of the earth with a view to a possible intercommunication.

(Kant 1795/1903: 138)

So mobility is somehow both a natural requirement and a right, but the sole point of it is this "intercommunication", "Verkehr", which can refer to exchange, conversation, and trade, all of which the English translation then calls "intercourse". This then "naturally" leads to peace:

This right to hospitality, however - that is to say, the privilege of strangers arriving on foreign soil - does not amount to more than what is implied in a permission to make an attempt at intercourse with the original inhabitants. In this way, far distant territories may enter into peaceful relations with one another. These relations may at last come under the public control of law, and thus the human race may be brought nearer the realization of a cosmopolitan constitution.

(Kant 1795/1903: 139)

This is the crux of Kant's argument: increasing communication and exchange will, in and of itself, lead to understandings between nations, tolerance, and thus peace. The terms used for communication here are compatible with trade, and the argument could fit in with the claim that free international trade is beneficial for all parties involved (although Ricardo's On the Principles of Political Economy and Taxation would not appear until 1817).

Kant recognises that greater international mobility does not necessarily coincide with increasing hospitality, the logic of which is despoiled, says Kant, not only by the violence and the occupation forces of European colonialism but also by severe restrictions in China and Japan on the presence of foreigners. Hospitality thus stands in between the unacceptable extremes of occupying the space of the other and denying the entry of the other. It is a mid-point that has to be identified and defended. It alone can enable communication to flourish into a grand cosmopolitan solidarity, where all violations are connected and concern all:

The intercourse, more or less close, which has been everywhere steadily increasing between the nations of the earth, is now extended so enormously that a violation of right in one part of the world is felt all over it. Hence the idea of a cosmopolitan right is no fantastical, high-flown notion of right, but a 
complement of the unwritten code of law - constitutional as well as international law - necessary for the public rights of mankind in general and thus for the realization of perpetual peace.

(Kant 1795/1903: 142)

"A violation of right in one part of the world is felt all over it" - here we have the Brazilian fires, perhaps, in that the ecological moves us more than abstract morality. Most obviously, it moves us because it directly concerns everyone's self-interest. This is quite unlike prior situations where, as in Kant's world, one was moved against Apartheid because it violated the rights of a part of humanity, and thereby of all of us as parts of humanity. That kind of affect required huge doses of empathy, of seeing oneself in the other, and could draw on deep wells of historical guilt - one needs the images of the violence or the malnourished children. The ecological violation, the kind of cosmopolitanism I am interested in here, is much simpler and more direct: the climate will affect you.

But does it follow that the simple fact of communication will lead to peace? Any kind of communication? More to the point, in what language is all this communication supposed to happen? Kant makes only one mention of language here: "[Nature] employs two means to separate nations, and prevent them from intermixing: namely, the differences of language and of religion" (Kant 1795/1903: 156). So language differences apparently become a force working against mobility, hospitality, communication, and ultimately peace? Not quite: Kant does not seek the "intermixing of nations"; he is happy that they maintain their distinct identities; he implicitly assumes that each nation has just one language and just one religion; all he seeks is communication between them.

If the language differences are to be respected, Kant must then logically require some form of language learning or translation. But those things are not mentioned in his essay. One would like to attach Kant's vision to Antoine Berman's (1999) image of translation as an "auberge du lointain", a cultural "inn of the afar", where the voice of the foreigner can be welcomed, understood, and yet remain foreign. But that connection of language work with mobility, without integration, was not made by Kant, and Berman did not make the connection with anything like world peace.

\section{Goethe and the calling of translation}

References to the role of translation in cosmopolitan discourse occasionally take their lead from a slightly later moment. Goethe similarly observed the increasing trade between nations and, as is well known, he saw this as leading to the development of a world literature, which would in turn promote tolerance, albeit without headline claims to peace or natural rights. In Goethe, this vision is related to the work of translators. Among the regular citations, we find the following:

And thus every translator is to be considered a mediator [Vermittler] in this universal spiritual commerce [Handeln], and as making it their business [Geschäfft] to promote this exchange [Wechseltausch]: for say what we may 
about the insufficiency of translation, the work is and will always be one of the weightiest and worthiest affairs in the general concerns [Geschäfte] of the world.

(Goethe 1827/1887: 18) ${ }^{1}$

Translation textbooks tend to cite the "weightiest and worthiest" part ("wichtigsten und würdigsten", perhaps "most important and dignified"), which is wonderfully flattering to translators. What is not so uplifting, however, are the ironic uses of commercial terms here: "mediator", "commerce", "business", "exchange" - these are all words that do not seem quite so dignified when uttered in the realm of philosophy and literature. The dominant reference is very much to commerce and trade, now in a period following Ricardo's (1817/1821) demonstration of the benefits of free trade to all parties. Exchange is good, in commerce as in literature. All these terms concern exchange in the sense of giving something in exchange for something else:

The Koran says, "God has given to each people a prophet in his own tongue!" Thus each translator is a prophet to his people. [...] What indeed is the whole enormous business [das ganze ungeheure Geschäfft] of the Bible Society, but to make known the Gospel to all people in their own tongue?

(Goethe 1827/1887: 18-19) ${ }^{2}$

Here the exchange seems particularly one-sided. Whereas Kant had somehow assumed that each nation kept its one religion, now Goethe's international communication involves the spread not just of commerce, but of evangelical Christianity at least (I hesitate to enter the Quranic reference, which requires exegetes to explain why Mohammed could speak to many peoples). There is no indication in Goethe that the Christian gospel should receive hospitality of any kind, and certainly little historical evidence that it has entered new cultures merely to talk and to trade. And suddenly, I note, the mere translator as mediator has become not just dignified but also a prophet, with a voice that speaks directly to a people, in a kind of religiously legitimated commerce that is not just enormous ("ungeheure") but on the edge of monstrous ("ungeheuerlich"). One senses that the noble mission of world peace is here served with a skeptical undertone. But yes, translation is at least there.

\section{Marx and the awareness of asymmetries}

As I now re-read these old texts, a hundred alarm bells go off in the background. The German thinkers were surely describing the beginnings of globalisation, and they were doing so in terms that we would now see as naïvely optimistic. How could they possibly believe that trade alone would lead to spiritual understanding and universal peace? How could this possibly justify an invasive Christianity, among much else? The problem is not just that they confuse the

\footnotetext{
${ }^{1}$ Und so ist jeder Uebersetzer anzusehen, dass er sich als Vermittler dieses allgemein geistigen Handels bemüht, und den Wechseltausch zu befördern sich zum Geschafft macht. Denn, was man auch von der Unzulänglichkeit des Uebersetzens sagen mag, so ist und bleibt es doch eins der wichtigsten und würdigsten Geschäfte in dem allgemeinen Weltwesen.

2 Der Koran sagt: „Gott hat jedem Volke einen Propheten gegeben in seiner eignen Sprache““ So ist jeder Uebersetzer ein Prophet seinem Volke. Luthers Bibelübersetzung hat die größten Wirkungen hervorgebracht, wenn schon die Critik daran bis auf den heutigen Tag immerfort bedingt und mäkelt. Und was ist denn das ganze ungeheure Geschäfft der Bibelgesellschaft, als das Evangelium einem jeden Volke in seiner eignen Sprache zu verkündigen.
} 
movements of commerce with the complexity of cultures. It is also that their thinking is qualitative, without more than an ironic glance at the quantitative distributions of wealth, goods, and communicative capacity. Kant's global distribution does not go beyond the abstract individual; Goethe is prepared to ironise evangelism as commerce but somehow assumes it is all headed the right way in the end. To find critical awareness of the quantities behind the expansion of Western modernity, a rather different voice is required:

The need of a constantly expanding market for its products chases the bourgeoisie over the entire surface of the globe. It must nestle everywhere, settle everywhere, establish connections everywhere. The bourgeoisie has, through its exploitation of the world market, given a cosmopolitan character to production and consumption in every country.

(Marx and Engels 1848/1969: 38)

The passage comes directly after one of the more famous descriptions of modernity: "All that is solid melts into air, all that is holy is profaned" (Marx and Engels 1848/1969: 38). Yet what could be more solid than the data and technologies of world trade? What is more truly profaned here, I suggest, is the abstract illusion that exchange is carried out by whole societies and on the basis of equal benefits. Once you start to ask exactly how much wealth, how many people, and how mисh technology is moving, class and radical cultural asymmetries perturb any promise of global peace.

Marx does not mention language or translation here, unfortunately. But he does show what is wrong with any cosmopolitanism that is a purely qualitative affair of welcoming strangers or getting people out of bed for a good cause. The problem is that our more recent cosmopolitanisms are similarly devoid of quantities and can thus never be wrong.

\section{Ulrich Beck's cosmopolitan competence}

Translation, in a more complete sense, eventually became part of cosmopolitan discourse, since the problems of cultural differences (not just languages and religions) refused to go away. To take a prime example, Ulrich Beck, Professor of Sociology at Munich and the London School of Economics (with Anthony Giddens), saw translation as part and parcel of "reflexive modernity", which is a modernity that is able to relativise itself (I simplify, of course). Beck's project for a "cosmopolitan sociology" is thereby belligerently opposed to the non-reflective assumption of the nation state as the essential frame of how social groups operate ("the national fallacy") and any sociology based on that assumption ("zombie sociology"). Cosmopolitan sociology thus questions the dualisms of "nation state sociology". As such, it draws on postcolonial discourse and the aesthetics of métissage, incorporating a particular notion of translation:

Cosmopolitan competence, as a fact of everyday and scientific experience, forces us to develop the art of translation and bridge-building. This involves two things: on the one hand, situating and relativizing one's own form of life with other horizons of possibility; on the other, the capacity to see oneself from the perspective of cultural others and to give this practical effect in one's own experience through the exercise of boundary-transcending imagination.

(Beck 2004/2006: 89) 
This opening to the other and relativisation of the self shares much with the philosophy of dialogue, particularly the hermeneutics of Ricœur (2004). It is not, however, a simple opening up to the other. Beck emphasizes that we are collectively exposed to risks that concern more than one nation (the "risk society"), such as global warming, human trafficking, epidemics, and natural disasters. Supranational (cosmopolitan) thought and action thus become rationally necessary, and the intervention of one culture into another is therefore considered legitimate:

The desire for a quiet life is justified with the argument that the chasms between cultures are too wide to be bridged. This may be tendentious and false as regards the motivation for relativism. But the incommensurability assumption amounts to a non-intervention pact between cultures that can easily degenerate into violence in a world where non-intervention is impossible because intervention has always been the norm.

(Beck 2004/2006: 55)

These are brave, self-assured words; they break entirely with the assumption, found in Kant and Goethe, that cultures are basically separate and should not be changed; mutual respect and understanding are no longer enough, or even necessary. These words are formulated within a culture (a Western academic culture) that clearly considers itself to have sufficiently developed "the art of translation and bridge-building", to have a sufficiently "boundary-transcending" imagination, to effectively compromise Kant's fundamental right to hospitality. Here the act of translation has been raised to a level of certitude that claims far more than a passive place in the culture of the other: translators can indeed claim the right not just to be prophets, but to invade.

Beck's reference to translation is perhaps no more than a convenient metaphor, as is so often the case - a figure of speech pressed into service whenever we need something different from bad old national boundaries. It is a conceptualisation of translation without actual translations (there are no texts to construe) and economically without translators (although there must be people somewhere to enact interventions). The absence of people doing these translations might even seem out of place in a sociology, which is supposed to deal with societies or social relations. Needless to say, this abstract kind of translation also operates without attention to languages and religions, those things that Kant recognised might help make societies different and could complicate communication.

\section{Gerard Delanty's logic of cultural translation}

What in Beck is little more than a passing reference to translation becomes something closer to an intellectual dependence on translation in the work of Gerard Delanty, a British Professor of Sociology and Political Thought, who brought together various strands of "cosmopolitan studies" into a landmark Routledge handbook (2012). Delanty's own take on cosmopolitanism and translation can be found in The Cosmopolitan Imagination (2009: 13):

The cosmopolitan imagination entails a view of society as an ongoing process of self-constitution through the continuous opening up of new perspectives in light of the encounter with the Other.

So far, so good: this is in Beck (2004/2006) and remains easy to agree with, as long as nothing happens. Then: 
[...] this is discussed along the lines of the logic of translation, here understood as cultural translation. It is the nature of translation that the very terms of the translation are altered in the process of translation and something new is created. This is because every translation is at the same time an evaluation.

(Delanty 2009: 13)

Wait a minute! Here we have something that is not quite in Beck, for whom translation involves a kind of competence and "bridge-building". Now it means changing things, in a logic where the term "translation" seems to play three roles: the nature of the process, the thing whose terms are changed, and the process itself. This may seem logical to some. Fair enough: a whole string of theorists regularly point out that translations transform texts, changing some things in order to approximate others. But here it is apparently because of "evaluation", which makes little sense in this context but might if you spot Gadamer (1960/1975) in the mix. No matter - all is revealed in the following sentence:

Translation was once a means to communication and to render another culture intelligible, but with the advent of modernity translation became a cultural form in itself and can be understood as a paradigmatic third culture. With the principle that every culture can translate itself and others, came the possibility of incorporating the perspective of the Other into one's own culture.

(Delanty 2009: 13)

So "the advent of modernity" (not even waiting for postmodernity) magically put an end to translation as communication and thereby to all attempts to make the lingual other intelligible. In so doing, modernity definitively replaced the kind of translations that I do as a translator, and that I train students to do, with a "logic" that is possibly open to all logics:

Cultural translation is a process of mutations, transferences, innovations, appropriations, borrowings, re-combinations and substitution. It concerns the symbolic and cognitive processes by which cultural aspects of a given collective identity are appropriated by a different one, which will variously adapt, transfigure it, subvert it.

(Delanty 2009: 196)

So instead of the bad old translation that sought to render a culture intelligible, now we have a "cultural translation" that actively transforms a culture in numerous ways.

What bothers me here is not really the vague, impressionistic terms in which the concepts of translation are formulated, since there are numerous similar discourses on cultural translation and post-translation to be found. Nor is it really the lack of empirical knowledge that is at stake, since that is also a common enough feature of cultural-studies discourse. And I am not particularly perturbed by the blunt assumption that this new conceptualisation of translation has somehow immediately done away with the old one, since the kind of translation that attempts to "render another culture intelligible" is still alive, creative, communicative, paid for, and in use regardless. What irks me more profoundly is how this vague concept of cultural translation washes away the very problems that cosmopolitan discourse in Kant and Goethe might have been designed to address: the differences between languages (the stuff translators work on) and the fact of conversation (the things translators contribute to). Do away with those two factors, 
and the task of the cosmopolitan is easy: all you need is to adopt the right mindset, identify transformations everywhere, and the rest follows of its own accord.

When translation becomes "a central category of all communication", it has miraculously dissolved all the barriers to communication that might ensue from different languages and cultures. No one has to learn languages; no one has to mediate between them; the universal has been attained in the figure of translation itself; the monolingual knows all. Now all we need do is await perpetual peace.

\section{So how do people change?}

Let me cut the critique short: there is a lot of this kind of thing about, both in postmodern sociology and, increasingly, in translation studies. Concepts of "cultural translation" abound; they are all-embracing; they are easy to promulgate; they promise to analyse and perhaps change mindsets; they can certainly question the homogeneity of national categories and thus the simple binarisms once assumed by models of language translation. No one can say that one kind of translation is right and the other is wrong - that is far from my intention here. It is easy to pick at the way these theorists misconstrue language translation, but they are still asking some of the most important questions of our time.

What I want to ask is how the electrician in New Haven comes to care about Brazilian fires. The answer offered by cosmopolitan studies in its present state would seem to be that, since Brazilian and American cultures are heterogeneous and fragmented, part of one can enter into communication with part of the other, enact transformations, and thereby form a new kind of cultural entity: a transcultural community of interest. Yes, perhaps. But how, exactly? How were the different languages and cultures bridged? How did anyone find out about that shared community? Why did they decide to enter it? No notion of cultural translation seems fully able to answer those questions. The debates of cosmopolitanism appear more oriented to deciding what kind of social or cultural group might hold the keys to the future. But my question is how worldviews are changed.

Not having American electricians at my immediate disposal, I ask about another group: Afrikaans-speaking academics, faute de mieux.

\section{Notes on a failed research project}

Some years ago I was interested in how people break away from closed ideologies, particularly the ideologies that are so successful in explaining entire sets of social relations that they are technically called "totalitarian" (after Faye 1972). The totalitarian discourse would be one kind of opposite to cosmopolitanism: rather than extend hospitality to the other, it explains away all alterity through narratives of false consciousness, conspiracy, or a simple lack of moral virtue: enemies abound and are needed as a necessary way to identify the social self. In this kind of discourse, if the other enters your space, you throw them out or try to convert them to your cause.

My examples were academics who crossed my path: visitors from the Syria of Assad and liberal academics born into the Afrikaans-speaking South Africa of Apartheid. Both those regimes appeared to have ideologies that could explain everything a young person would want to know about the world; both could explain away the counter-narratives. Of course, I could have selected 
from any number of similar examples: from Erdoğan's Turkey to Xi Jinping's China, populist nationalism is on the rise, as indeed it is in the voting preferences of all Western constitutional democracies. And if you dig a little deeper, discourses of totalitarian closure are to be found not just in the religions that are growing most rapidly, but in all the ideological communities promoted by social media, where like talks to like and alterity is rendered invisible. The problem with the descriptions of cosmopolitan translation is not just that they separate translation from the harder realities of language, but also that, as a political project, it would seem to be swimming against the tide of history (cf. Zuckerman 2014). How many ideological battles does the cultural left have to lose before it senses that its theories are not working?

My project was simple enough: I set about interviewing people who grew up within totalitarian discourses. I was trying to see what made them see beyond the closure, what alerted them to the cracks in the systemic wall, what gave them their first glimpses of something like a cosmopolitan consciousness - which I am given to see as some kind of progress. My initial hypothesis was that people with several languages were more likely to develop cosmopolitan awareness, since they would theoretically have access to more sources of contrasting information; they could more easily enter the space of the other, see themselves from there, and use that as a process of change. In that sense, I was looking for instances of translation that might be working a particular kind of magic. That would hopefully be language translation, but I was prepared to recognise any form of translation if it achieved some kind of cosmopolitan consciousness.

So how did my interviewees change their worldviews? There are many indications in the data. Here I can only summarise a collective narrative of encounters, drawn from three of my South African interviewees ${ }^{3}$, all of whom deserve and will receive a more substantial account elsewhere. I select a few fragments that seem to address the problems of cosmopolitanism; I do not assume to address any wider context; I have no pretence to tell South Africans about who they are. I am simply looking for some of the reasons for changes that some Afrikaans speakers seemingly embody.

\subsection{Subject 1}

A girl growing up in a nationalist but multilingual family learns to see herself from the outside. Several languages are in place in her upbringing: Afrikaans, German, Dutch, English, and then French, since she goes on a study visit to France and returns to become a teacher of English. The cracks first appear within the nationalist family, whose dominant ideas she opposes, then abroad:

An elder brother says he is not going to vote: "He does not agree that the government will not let Maoris come to play rugby."

Later, visiting Europe, a "Whites Only" photograph is seen in the Anne Frank House: "How strange to see this in a foreign country."

On a study visit in France: "We were brainwashed [in South Africa, prior to leaving] with the idea that they [the Europeans] would be against you, brainwashed by the government and the media."

\footnotetext{
${ }^{3}$ Interviews conducted in Stellenbosch in March 2012 and Bloemfontein in March 2014. They lasted 48 minutes, 58 minutes, and 47 minutes respectively.
} 
"There was a lot of animosity when they found out you were from South Africa." "I felt they did not understand, but I was definitely not proud of that."

Travelling abroad with her husband: "On a night train in Europe, we had a lovely conversation with a non-white man. Until we said we were South African."

"I discovered that others don't see us the way we see us."

A limited cosmopolitanism emerges through contacts with the outside: very indirectly in instances like that of the New Zealand rugby team, then more directly in the trips abroad, the photo that speaks anew simply because it is in another country. When discussing South Africa with the host family in France, she tried to explain her reality but was "silenced". There was much kindness with the learning of a language, but no particular hospitality to South African ideas, and boycotts would later limit the possibilities of encounters abroad. There were few conversations that could lead to anything like Kant's perpetual peace. Yet a process was underway: the self was seen from the other's perspective.

The languages here were not the direct cause of any opening to the other. They came bundled with the social class that enabled movement, yet the encounters abroad, justified by language learning, were then the triggers for self-questioning.

In sum, this is a case of what we have seen Beck (2004/2006: 89) describe as translation "situating and relativizing one's own form of life with other horizons of possibility, [developing] the capacity to see oneself from the perspective of cultural others". And yes, one can see here that the intellectual process is something like language translation, seeing the self from the outside. Moreover, the end result has indeed worked from "the possibility of incorporating the perspective of the Other into one's own culture" (Delanty 2009: 13). These forms of translation can contribute to a certain fact of conversion: a more open consciousness was formed, but it would not necessarily be moved by Amazonian rainforests.

\subsection{Subject 2}

A girl grows up in an Afrikaans-speaking family, although her father is German and she learns to speak German as well as English. At university, she then studies French and Dutch, before being definitively seduced by the linguistics of Afrikaans. A language complex is certainly in place, yet in this case the origins of dissent are in the family itself.

"From 12 to 18 I was rebellious against the whole system." "I knew better from home."

When with nationalist Afrikaner friends growing up: "It was strange for an Afrikaans speaker [like me] to be against the system." "I did have people with me, usually immigrant people. My best friend was a German girl."

At university, she finds that other Afrikaans speakers were also "renegades". The student body invites writers like André Brink: "And Nadine Gordimer, but she didn't speak to me like the Afrikaans writers; I wanted to read people like myself." 
"I never had English-speaking friends. I thought that all the English speakers were against the system, and I thought I thought like them."

She never went into a Black township: "I imagined it would be just horrible, very cold." "I was never aware of being in a minority, as a white South African. The others were just invisible."

"The end of Apartheid came because the government did not want civil war. Not because of boycotts, I am sure of that."

One might doubt there is anything properly cosmopolitan in the narrative. The girl became a woman conscious of her disagreement with those around her, finding support for dissent in the family setting, using it against totalitarian schooling, then seeking out other, similar minds and finding them at university, where she was happy and where she stayed. Despite various visits abroad, initially with the extended German family, those external experiences do not figure in any narrative of change: she feels herself to be an outsider (a friend of immigrants) who then met other outsiders, but definitely within her country. What is stressed here, repeatedly, is the need to find affirmation of the self by seeking out people similar to the self. The purely qualitative nature of person-to-person experience obviates awareness of quantities, as in classical cosmopolitan theory: the masses remain invisible. And encounters with external others seem not to be particularly effective: boycotts, in particular, were not changing her ideas, were not having a political effect, and simply got in the way of potential hospitality - a boycotting foreigner will not understand her experience of personal difference. This may not be cosmopolitanism in any full sense (there is little interaction with the Blacks or English in her own country); this is not cultural translation as interaction with the other: it seems more like mutual affirmation of liberal dissent, identified with a particular view of the nation, where she feels at home.

\subsection{Subject 3}

The boy becomes a man on a sheep farm in the west of the Karoo, in a border region where Afrikaans, English, and isiXhosa all mix. He is from a nationalist family, which he eventually opposes. He speaks Afrikaans, picked up just a little isiXhosa, and learned the obligatory English. His path leads to theology, ordination as a priest, then commitment to anti-imperialism as an academic.

On the history learned at school: "Lots of barbarians, until colonized. And Christianity came. The big enemy was the British, who brought laws and taxes." "The British were the enemy, sometimes more than the Blacks."

Arguing with a schoolboy of mixed English and Afrikaans-speaking background: "What's the difference between marrying an English woman and a Black woman?". He asks a question that should not be asked and he himself cannot answer.

Second year at university (around 1984). Asked to read André Brink's Kennis van die Aand ${ }^{4}$ in the philosophy class: "It scared the shit out of me" because of the sexuality and the interracial theme. "That changed my whole life. It was the first time I saw the other side of Apartheid."

\footnotetext{
${ }^{4}$ Kennis van die Aand was published in 1972 and banned in January 1974 (the first Afrikaans novel to be banned by the South African government). Brink self-translated the book and published it as Looking on Darkness (1973).
} 
"It showed me what I suspected, that there were people on the other side." And so he starts to seek out and talk with people on the other side.

"Theology was a source of intellectual power." "I wanted to change the world." But then: "I was not frightened by the politics but by the church."

"But in the Hebrew department, every teatime there were discussions."

When asked if there was one person who had influenced him: "Yes, my supervisor in the Hebrew department. We had one-on-one discussions."

At one point, he wants to study with Robert Alter at Berkeley but cannot because of boycotts. He does not travel outside South Africa until 2007.

Once again, the languages were present but somehow not important. As the interviewee commented when asked about languages as possible openings to other worldviews, "[m]any of your biggest racists can speak Xhosa". What stands out here are instead conversations (in unnamed languages) as political acts: the rhetorical taunting of an English-speaking schoolboy, the political discussions in a particular academic department, the one-on-one exchanges with a supervisor, and then the decision to talk with "people on the other side". The "other side" implies a border within the nation, as with Subject 2: there is no need to travel outside of South Africa in order to seek hospitality, but this is the one instance where the border is explicitly calqued on race. And here, yes, reading a literary text has a profound effect, but perhaps also as written conversation with a fellow Afrikaans speaker, and certainly as an opening to further conversations within the same language.

Despite all those remembered encounters, in the interview of 47 minutes there is no mention of how the self was perceived by the other, no comment on interiorisation of the external gaze, no problematic translation in that interpersonal sense. When the interviewee named "the British" as the early perceived enemy and yet spoke with an English speaker, there is no mention of how that other might have reacted to his rhetorical question, "What's the difference between marrying an English woman and marrying a Black woman?". That is not to say that some deep interpersonal translation was not going on, but it was not verbalised here. And although that same relative absence might be noted for Subject 2, there is an intriguing difference between the two: Subject 2 was seeking out people who thought like her and were like her (Afrikaans speakers, not English speakers), whereas Subject 3 went out to seek hospitality "on the other side", among people who were rigorously not like him.

So what can we learn about cultural translation and cosmopolitanism from these three cases?

First, most obviously, although all subjects are reasonably complex polyglots, translation across languages themselves plays no major role in the narratives. Afrikaans is often mentioned as a feature of self-identity, and other languages are certainly thereby named when indicating other social identities, but there is no need to name translation as a necessary bridging: these people know languages, so the linguistic part of the bridging just happens. When literature enters the frame, it is most powerful when in the language of the self (the Afrikaans-writing Brink has an effect, but not the English-writing Gordimer). So language translation is neither a force nor an issue in these narratives. Much as languages might constitute barriers to overcome in the 
cosmopolitan views of Kant and Goethe, the overcoming itself does not guarantee any necessarily cosmopolitan vision.

Second, no matter how much the national frame may have been theorised out of cultural studies ("the national fallacy", for Beck (2004/2006)), nations and ethnic groups appear and reappear throughout the narratives as strong closed frames, most forcefully in the first subject's encounters abroad but also in all the subjects' awareness of boycotts. The politics of boycotting (in their form, whatever the historical context) affirm the national, making all these people aware that they are addressed from the outside as being South African before all else. And even within the country, when the enemies are seen as the British and/or the Blacks, the frame is one of separated cultures, without cultural translation between them. That is what Apartheid meant, after all. Despite Delanty's (2009) self-righteous delusions to the contrary, modernity did not magically make the divisions disappear.

Third, although these are all academics prepared to support international good causes, only the first subject could be said to have changed because of hospitality abroad in anything like Kant's (1795/1903) sense. And the hospitality was no affair of erudite ruminations on the ways of the world: she was staying in people's houses where she was told how bad her country was. As the hermeneutic models suggest, cultural translation can be a rough trip!

And fourth, one might hopefully trace a gradual transition to something like Kant's primary law that the stranger "must not be treated as an enemy". These are all people (like all of us, if the timeframe is long enough) whose ancestors came as strangers, occupied land, and were treated as enemies. The narratives of life under Apartheid are then riddled with enemies, real or imagined: the Blacks, the British, the nationalists, the racists, the church, the police, the boycotters, and the youthful imagination of Subject 3 even imagined the South African army could take on the Russians and the Americans if necessary - there was no shortage of enemies! That was a world of divisions with scant hospitality. The trajectories of our subjects then move towards encounters with others who are no longer seen as enemies. The end of Apartheid at least brought the possibility of hospitality, and perhaps of cultural translations.

There is a further meta-level here, that of the interviews themselves as a space of potential hospitality. In my own experience of South Africa as a young English-speaking man, albeit only for slightly less than two years in the mid-1970s, the Afrikaans speakers were broadly an enemy, a group for whom I learned several quite disrespectful names. I saw them as being collectively responsible for the social iniquities I witnessed, and I rejected any suggestion that their historical experience might be similar to that of white Australians. These short interviews were thus something like speaking with the enemy, allowing them a potential legitimation that they might not wholly deserve. The spoken exchanges did not overcome that suspicion; there was no magical welcoming of the other; nothing was taken at face value. Yet there was a kind of translation happening at the receiving end, my end, as I mentally mapped much of what was said back onto my own memories of similar events in my own past. I became aware that, in more respects than I had previously admitted to myself, issues of race are just as uneasy within the culture I have most inherited. Is that an act of translation?

All in all, one wonders whether the concepts of cosmopolitan translation (or cultural translation) can really be applied to these narratives with any kind of precision. Those concepts perhaps come from a different slice of the world, or from hopeful imaginings of a very theoretical kind. If you 
want to study how young people grow up when surrounded by closed ideologies, you might do better to consider parameters like how much energy (agitation, conflict, intellectual work) is in the cultural system (cf. Even-Zohar 2016) or indeed how much social turbulence a person has to navigate in order to find a way through (cf. Marusic, Damousi and Broomhall 2018). As noted, these were rough rides, even for those of us who benefited from relatively easy pathways.

\section{Eternal peace?}

It is not infrequently remarked that the title of Kant's essay, Zum ewigen Frieden, is not just a search for peace on earth but was taken from the entrance to a graveyard - perhaps the only sure kind of perpetual deliverance. On the way to that silent end of history, we live with constant measures of conflict, and it would be very naïve to assume that the electrician in New Haven was suddenly enlightened to Brazilian rainforests and that is the end of the story. I have not met the electrician, but the three people I did meet here have been on long, tortuous, uncomfortable paths of at least partial self-translation. And there can be no suggestion that any end has been reached.

My small interview-based research has perhaps failed because it has only discovered what evangelists have always known: that people most profoundly change through one-on-one conversations. Those are the occasions that hospitality allows, and the cause of hospitality might yet be worth supporting. A one-on-one conversation can come in the form of a deeplyread book, of course, and even in the form of an interview.

Now, what might the opposite of hospitality be? Totalitarian discourses of enemies and conspiracies perhaps, but also, in this context, boycotts, at least insofar as they deny dialogue and impose national frames. The diffuse effects of political turbulence are not to be denied, but if one is to believe my interviewees, boycotts of South Africa brought us no closer to eternal peace there than they have in translation studies.

\section{References}

Beck, U. 2004/2006. The cosmopolitan vision. Cambridge: Polity.

Berman. 1999. La traduction et la lettre, ou l'auberge du lointain. Paris: Seuil.

Chanda, N. 2007. Bound together: How traders, preachers, adventurers, and warriors shaped globalization. New Haven, CT: Yale University Press. https://doi.org/10.1111/j.1540$\underline{6563.2008 .00227 \quad 70 . x}$

Delanty, G. 2009. The cosmopolitan imagination: The renewal of critical Social Theory. New York: Cambridge University Press.

Delanty, G. (ed.) 2012. Routledge handbook of cosmopolitan studies. London and New York: Routledge.

Derrida, J. 1997/2001. Cosmopolites de tous les pays, encore un effort! [Trans. M. Dooley and M. Hughes as On cosmopolitanism and forgiveness]. London and New York: Routledge. 
Derrida, J. and A. Dufourmantelle. 2000. Of hospitality. Palo Alto, CA: Stanford University Press.

Even-Zohar, I. 2016. Ideational labor and the production of social energy: Intellectuals, idea makers and culture entrepreneurs. Tel Aviv: Culture Research Lab.

Faye, J.P. 1972. Langages totalitaires: La raison, critique de narrative, l'économie. Paris: Hermann.

Gadamer, H.G. 1960/1975. Wahrheit und Methode. Grundzüge einer philosophischen Hermeneutik. $4^{\text {th }}$ edition. Tübingen: J.C.B. Mohr.

Goethe, J.W. von 1827/1887. Letter to Carlyle, July 20. In C.E. Norton (ed.) Correspondence between Goethe and Carlyle. London and New York: Macmillan. pp. 13-27.

Habermas, J. 1995. Kants Idee des Ewigen Friedens - aus dem historischen Abstand von 200 Jahren. Kritische Justiz, 28(3): 293-319. https://doi.org/10.5771/0023-4834-1995-3-293

Kant, I. 1795/1903. Zum ewigen Frieden. [Trans. M. Campbell Smith as Perpetual Peace.] London: George Allan \& Unwin.

Marusic, I., J. Damousi and S. Broomhall. 2018. Turbulence isn't just a science problem. Available online: https://theconversation.com/turbulence-isnt-just-a-science-problem-97171 (Accessed 22 April 2021).

Marx, K. and F. Engels. 1848/1969. Manifesto of the Communist Party. In Marx/Engels Selected Works, Vol. 1. Moscow: Progress Publishers. pp. 98-137.

Ricardo, D. 1817/1821. On the principles of political economy and taxation. 3rd edition. London: John Murray.

Ricœur, P. 2004. Sur la traduction. Montrouge: Bayard.

Zuckerman, E. 2014. Digital cosmopolitans. Why we think the Internet connects us, why it doesn't, and how to rewire it. New York: Norton.

https://doi.org/10.1080/10253866.2014.952921 